\title{
Story Retelling Analyses as a Function of Visual Cues using Information Units for Persons with Aphasia
}

\author{
Ye Na Kim, Jee Eun Sung \\ Department of Communication Disorders, Ewha Womans University, Seoul, Korea
}

\author{
Correspondence: Jee Eun Sung, $\mathrm{PhD}$ \\ Department of Communication Disorders, \\ Ewha Womans University, 52 Ewhayeodae-gil, \\ Seodamun-gu, Seoul 03760, Korea \\ Tel: $+82-2-3277-2208$ \\ Fax: +82-2-3277-2122 \\ E-mail: jeesung@ewha.ac.kr
}

Received: October 5, 2017

Revised: November 26, 2017

Accepted: December 6, 2017

This work was supported by the Ministry of Education of the Republic of Korea and the National Research Foundation of Korea (No. NRF2017R1A2B4006604)

\begin{abstract}
Objectives: The purpose of this study was to investigate performance on story retelling procedures in persons with aphasia (PWA) depending on the presence of visual cues using information units (IU). In addition, IU metrics were correlated with linguistic measures and aphasia severity. Methods: Fifteen PWA and 15 age- and education-matched normal individuals participated in the study. A familiar story was presented either under auditory only (AO) or auditory visual (AV) conditions in story retelling procedures. Dependent variables from IU checklists included number of IU (\#IU), percent of IU (\%IU), number of IU per minute (\#IU/min), and percent of IU per minute (\%lU/min). Results: PWA demonstrated significantly worse performance than the normal group across all IU-related measures. The main effect for the condition was significant in \#IU and \%IU with better performance on the AV than $\mathrm{AO}$, whereas the main effect was not significant for \#IU/min and \% IU/min. The twoway interaction was not significant in any of the IU measures. There were significant correlations among IU metrics and linguistic outcomes (number of utterances, number of words per minute, words, \#CIU, \#CIU/min, \%ClU, and \%ClU/min). IU-related measures were also correlated with aphasia severity. Conclusion: Visual cues were beneficial for eliciting more linguistic units from persons with aphasia. The current study is the first attempt to apply IU metrics to Korean speakers with aphasia, confirming the clinical utility of IU metrics as an efficient method for analyzing the connected speech samples produced by persons with aphasia.
\end{abstract}

Keywords: Aphasia, Story retelling, Visual cue, Information units (IU)
실어증이란 좌반구의 손상으로 대화 상대자의 말을 이해하거나, 구어로 자신의 의사를 표현하지 못하는 등 언어의 전 영역에 걸쳐 서 어려움을 보이는 장애를 말한다(McNeil \& Pratt, 2001). 실어증 환자의 여러 가지 언어적 결함 중 담화수준에 대한 평가는 중요하 게 여겨진다. 왜냐하면 실어증 환자들의 궁극적인 목표가 될 수 있 는 의사소통은 단순히 정확하고 올바른 문장을 조직할 수 있는 능 력 그 이상의 것을 요구하기 때문이다(Yang \& Kim, 2006). 하지만 기존의 검사도구로는 실어증 환자의 의사소통 능력을 파악하는 것 은 쉽지가 않다. 국내에서 흔히 사용되는 따라 말하기, 사물-그림 이름대기, 문장 완성하기와 같은 기존의 공식 검사는 과제가 단순 하고 평가의 환경이 구조화되어 있어 환자의 정확한 의사소통 능력 을 측정하는 데 제한이 따른다(Im, Kwon, \& Sim, 2001). 이러한 언 어검사의 한계를 보완하기 위한 방안으로 제안된 평가가 자발화 분
석이다(Koo \& Choi, 2015). 자발화 평가는 말 산출을 통한 의사소 통 능력을 총체적으로 반영할 수 있으며 체계적으로 의사소통 능 력을 분석할 수 있기 때문에 표현언어 진단에서 매우 중요하다(Im et al., 2001).

언어장애군의 자발화 능력을 평가하기 위해 사용된 방법들을 살 펴보면 이야기 말하기(story telling), 이야기 다시말하기(story retelling), 이야기 생성하기(story generating), 대화(conversational), 구조화된 인터뷰(scripted interviews), 그림 묘사하기(picture description)와 같은 방법들이 주로 사용되었다(McNeil, Doyle, Park, Fossett, \& Brodsky, 2002). 그 중에서 이야기 다시말하기 과제는 연 속적인 구어를 유도하는 방법으로써 아동에게만 국한되지 않고 성 인에게도 많이 사용되고 있다(Sonh \& Kang, 2006). 이야기 다시말 하기 과제는 표준화된 평가도구보다 대상자와 관련된 다양한 언어 
정보에 대한 분석이 가능하게 하며(Pickert \& Chase, 1978), 언어 정 보 입력을 이야기라는 구조를 통해 통제할 수 있다는 측면에서 자 발화수집 과제로 자주 사용되어 왔다(Gazella \& Stockman, 2003). 이야기 다시말하기 과제의 이러한 용이성 및 효율성 때문에 실어증 환자와 같은 신경언어장애군의 언어적 결함을 살펴보는 과제로 많 은 연구에서 사용되고 있다(Azuma \& Bayles, 1997; Bayles \& Boone, 1982; Brodsky et al., 2003; Doyle et al., 1998).

이야기 다시말하기 과제는 대상자에게 이야기를 들려준 후, 그 이야기를 산출하도록 요구하는 과제로써 단서제시 유형이 대상자 의 수행력에 영향을 미치는 것으로 알려져 왔다. 이야기의 단서제 시 유형은 주로 시각적 단서 유무에 따라 달라질 수 있다. 즉, 이야 기 다시말하기 과제를 실시할 때 시각적 단서로써 그림을 함께 제시 하는 방법을 사용하거나, 그림 자극 없이 이야기를 청각적으로만 들려주는 형식으로 단서 유무를 조작하여 이야기 다시말하기 수행 력에 미치는 영향을 살펴본 연구들이 보고되고 있다. Karri 등(2002) 에서는 문장 단위의 발화가 어려운 10 명의 실어증 환자에게 그림단 서 유무에 따른 이야기 다시말하기를 비교하였다. 그 결과 그림단 서가 있는 조건과 없는 조건 간의 유의미한 차이가 나타나지 않았 다. 하지만 각 대상자를 세부적으로 분석한 결과, 그림단서가 제시 된 경우에서 10 명 중 4 명이 발화 수, 단어 수, 문장 수, 명사 대 동사 의 비율 등 발화의 양적인 면에서 긍정적인 효과를 보였다고 설명 하였다. 또 다른 선행연구(Doyle et al., 1998)에서는 세 가지 이야기 다시말하기 조건에서 실어증 환자의 언어이해력과 표현력에 미치 는 영향을 비교하였다. 연구에서는 언어적 수준을 모두 통일한 12 개의 이야기를 사용하였다. 이야기 다시말하기 조건은 이야기 제시 와 산출 시 모두 그림을 제시하는 경우, 이야기 제시에서만 그림을 제시하고 산출 시에는 그림을 제시하지 않은 경우, 마지막으로 이 야기 제시와 산출 시 모두 그림을 제시하지 않은 경우였다. 그 결과; 실어증 환자의 개개인마다 수행력이 증가한 조건이 모두 달랐으며 이야기 주제(story proposition), correct information unit (CIU) 수, $\mathrm{CIU}$ 비율, 분당 $\mathrm{CIU}$ 수와 같은 정보내용(information content)에 서 차이가 나타났음을 설명하였다. 결과적으로 실어증 환자의 산 출 능력은 다양한 자극의 양식을 제공받을 때 더 많은 도움을 받는 것으로 나타났으며 자극 유형이 언어표현력에 상당히 영향을 끼친 다고 하였다.

발화 분석연구에서 빈번히 사용되고 있는 CIU는 Nicholas와 Brookshire (1993)가 신경언어장애 환자군의 의미적 특징을 파악 할 수 있는 수단으로써 제안한 방법이다. CIU란 문맥상 명료하며 주제 혹은 과제에 적합하고 정확한 정보를 제공하는 낱말이다(Kwon, Kim, Choi, Na, \& Lee, 1998). CIU는 대상자가 사용한 낱말 중에 이
야기와 관련이 없거나 적합하지 않은 내용들은 제외하여 정보전달 능력을 평가할 수 있다. 이때 산출한 이야기가 문법적으로 반드시 정확할 필요는 없다. $\mathrm{CIU}$ 는 낱말단위이기 때문에 환자 간 수치로 객관적인 비교가 가능하며 과제에 구애 받지 않고 분석의 단위를 일괄적으로 적용할 수 있다는 장점이 있다(Kwon et al., 1998; Nicholas \& Brookshire, 1993). CIU 분석체계 중에서 CIU 수는 정보 전 달의 양을 살펴볼 수 있으며 $\mathrm{CIU}$ 비율 및 분당 CIU 수는 정보전달 의 효율적인 측면을 평가할 수 있다(Im et al., 2001). 하지만 이러한 정보전달력이나 임상적 효율성이 입증되었음에도 불구하고 $\mathrm{CIU}$ 분석 방법에는 몇 가지 한계점이 있다. 우선, 환자가 주어진 과제의 주제에 대해 핵심적인 내용을 파악하고 있는지 평가하는 것이 제 한되며(Nicholas \& Brookshire, 1995), 무엇보다도 분석 방법을 적 용하기 위해서는 대상자가 산출한 발화를 전사해야 한다. 따라서 많은 시간과 노력이 필요하며 임상에서의 용이성이 떨어진다는 단 점이 있다. 이러한 이유로 비교적 쉽고 간략한 절차와 채점기준이 필요하게 되었고 정보단위(information unit, IU)라는 분석체계가 제안되었다(McNeil, Doyle, Fossett, Park, \& Goda, 2001).

$\mathrm{IU}$ 란 특정 이야기와 관련이 있으며 정확한 정보를 전달하는 이 해 가능한 낱말이나 구를 말한다. IU를 분석하기 위해 발화 수집은 이야기 다시말하기(Doyle et al., 1998)를 통해 이루어지며 환자가 산출해야 할 목표 IU는 체크리스트에 이미 제시되어 있다. 임상가 는 환자가 다시 말하는 이야기를 들으며 해당하는 IU에 표시하여 $\mathrm{IU}$ 수를 산출하고, 총 IU 중 산출한 IU가 차지하는 비율(percentage of Information Units, \%IU)을 산출하여 발화분석을 하게 된 다. 이와 같이 IU 분석체계는 환자의 발화를 모두 전사할 필요가 없 기 때문에 임상적으로 유용한 분석체계라고 보고되고 있다(McNeil et al., 2001). McNeil 등(2001)에서는 이야기 다시말하기에 대 한 산출과 이해과제를 통해 IU의 분석체계에 대한 신뢰성과 동시 타당도를 분석하였다. 실어증 환자 15 명과 정상 성인 31 명을 통해 연구한 결과, 실어증 집단에서 IU 비율이 CIU를 포함한 다른 언어 적 측정치와 가장 높은 상관도를 보였다. 반면 IU 비율과 구어적 산 출(verbal productivity), 구어적 붕괴(verbal disruption measures) 혹은 문법성(grammatical)과는 상관도가 없거나 낮았다. 그럼에도 불구하고 정상 집단에 비해 실어증 집단의 IU 비율이 더 저조하였 으며 실어증 환자와 정상 집단을 감별하는 측정도구로써 IU 비율 이 가지는 신뢰성과 타당성을 입증하였다.

그 이후 McNeil 등(2002)에서는 IU를 산출하는 데 소요된 시간 으로 나누는 분당 IU 비율(percentage of IU per minute, \%IU/min) 을 사용하는 것이 장애집단과 장애유형을 정확하고 합리적으로 변 별하는 데 효율적이라고 주장하였다. McNeil 등(2007)에서는 이야 
기 다시말하기 과제에 따른 분당 IU 비율과 기존의 발화 측정요소 인 구어적 산출(verbal productivity), 정보내용(information content), 문법성(grammatical), 구어적 붕괴(verbal disruption measures) 간의 상관관계를 살펴보았다. 그 결과, 분당 IU 비율이 구어 적 산출(verbal productivity), 정보내용(information content)과 관 련된 이야기 주제(story proposition), 분당 낱말 수, CIU 수, CIU 비 율, 분당 CIU 수와 상관도가 높게 나타났다(McNeil et al., 2007). 또 다른 선행연구(Hula, McNeil, Doyle, Rubinsky, \& Fossett, 2003)에 서는 실어증 집단과 정상 성인의 이야기 다시말하기에 대한 오디오 녹음을 직접 듣고 분당 IU 비율에 대한 평가자 간 신뢰도를 측정하 였다. 그 결과 평가자 간 신뢰도에 대한 상관계수가 .89-995로 나타 났다. 즉, IU의 측정방법은 임상적 유용성뿐만 아니라 최소한의 훈 련만으로도 평가자 간 신뢰도의 차이를 최대로 줄일 수 있는 분석 체계임을 밝혔다. 이와 같이 분당 IU 비율은 이야기 다시말하기를 수량화하는 데 아주 중요한 측정 기준이 되었으며 많은 선행연구 에서 사용되었다(Brodsky et al., 2003; Hula et al., 2003; McNeil et al., 2002, 2007).

최근 국내에서도 한국어를 사용하는 정상 노년 및 청년 집단(Kim \& Sung, 2014; Sohn \& Kang, 2006)과 MCI 집단을(Kim, 2014) 대 상으로 IU 분석을 실시한 바가 있다. 그 결과, Sohn과 Kang (2006) 에서는 연령에 따라 IU 산출에 유의한 차이가 있었음을 밝혔으며 정상 노년층이 정상 청년층에 비해 담화능력이 저하되었다고 설명 하였다. 신경장애 집단을 대상으로 실시한 $\mathrm{Kim}$ (2014)에서도 IU 분석체계가 정상 집단으로부터 MCI 집단을 효율적으로 변별해낸 다고 보고하였다. 국내에서 IU 분석을 적용한 Kim과 Sung (2014) 에서 한국어 실정에 맞게 기존의 IU 분석기준을 수정하여 문법적 인 표지 역할을 하는 조사와 결속장치의 역할을 하는 접속사를 IU 에 포함하였다. 따라서 국내에서 사용한 IU는 어휘-의미론적인 측 면뿐만 아니라 의미를 내포한 구문론적인 측면을 함께 살펴볼 수 있는 장점이 있다. Kim (2014)에서는 IU 분석이 발화를 직접 전사 해야만 측정할 수 있는 문법적인 척도들과 기존의 발화 분석 변수 간의 높은 상관도가 있는 분석체계로써 임상에서의 효율성 및 타 당성을 논의하였다.

본 연구에서는 국내외 선행연구를 바탕으로 IU를 적용하여 한 국 실어증 환자에게 이야기 다시말하기 수행을 분석해보고자 한 다. 하지만 국내에서는 아직 실어증 환자를 대상으로 한 IU 분석체 계의 도입은 찾아보기 힘들며 한국 실어증 환자에게 IU 분석을 적 용하는 것에 대한 유용성 및 타당도 연구가 부족한 실정이다. 따라 서 본 연구의 목적을 다음과 같이 설정하였다. 첫째, IU 분석을 적 용하여 시각 단서 유무에 따른 실어증 환자와 정상 집단 간 수행차
이가 유의한지를 살펴보았다. 둘째, 실어증 환자군에서 IU와 언어 측정 변수들 간의 상관관계를 분석하여, 기존에 사용되고 있는 자 발화 분석기준 변수들과의 상관도가 어떠한지 살펴보았다. 마지막 으로, 실어증 중증도(AQ)와 실어증검사의 하위항목인 유창성, 내 용전달, 알아듣기, 따라말하기, 이름대기와 IU 간의 상관관계를 분 석하여, 표준화된 검사도구와 IU 분석의 타당도를 검증하고자 하 였다. 구체적인 연구 질문은 아래와 같다.

첫째, 시각 단서 유무(청각 vs. 시각-청각)에 따른 IU 측정 변수 (IU 빈도, IU 비율, 분당 IU 빈도, 분당 IU 비율)에서 두 집단(실어 증 vs. 정상) 간차이가 유의한가?

둘째, 실어증 집단에서 시각 단서 유무에 따른 IU 측정 변수와 기존의 언어측정 변수(발화 수, 낱말 수, 분당 낱말 수, 발화당 낱말 수, $\mathrm{CIU}$ 수, $\mathrm{CIU}$ 비율, 분당 $\mathrm{CIU}$ 수, 분당 $\mathrm{CIU}$ 비율) 간의 상관관계 가 유의한가?

셋째, 시각 단서 유무에 따른 IU 측정 변수와 실어증 환자의 중증도 (실어증 지수) 및 실어증검사의 하위항목간의 상관관계가 유의한가?

\section{연구방법}

\section{연구대상}

본 연구의 대상자는 정상 성인 15 명과 뇌졸중으로 인한 실어증 환자 15 명을 대상으로 하였다. 두 집단은 모두 (1) 한국어를 모국어 로 사용하며, (2) 오른손잡이고, (3) 서울신경심리검사 2판(Seoul Neuropsychologic Screening Battery-II, SNSB-II; Kang, Jang, \& $\mathrm{Na}, 2012)$ 의 하위검사인 글자 지우기(letter cancellation) 과제를 통 해 그림자극의 시각적 정보처리에 문제가 없으며 무시증후군이 없 는 대상으로 선정하였다.

실어증 환자는 (1) 좌뇌의 피질 및 피질하 부위의 뇌졸중에 기인 하여 언어장애를 보이는 자, (2) 한국판 웨스턴 실어증검사(Korean Version-Western Aphasia Battery, K-WAB; Kim \& Na, 2001) 결과 실어증으로 분류된 자, (3) 발병 이전에 뇌손상 및 기타 신경학적 질 환이 없었다고 보고된 자, (4) 검사지시 및 이야기에 대한 이해가 가 능하여야 하므로 K-WAB 결과 알아듣기 하위항목의 환산점수가 5 점 이상인 자, (5) Darley, Aronson과 Brown (1975)과 Duffy (2005) 에서 발췌한 마비말장애의 평가요소와 표준화된 읽기 문단 '가을' (Kim, 1996)을 기준으로 청지각적 평가에 따라, 중도 이상의 말운 동장애(motor speech disorders)를 동반한 환자는 제외하였다.

정상 성인은 (1) 실어증 환자군의 평균 연령과 평균 교육연수를 일치시킨 자, (2) Christensen, Multhaup, Nordstrom과 Voss (1991) 의 건강 선별기준에 근거하여 신경과 또는 정신과적인 병력이나 두 
Table 1. Demographic information of participants

\begin{tabular}{llcc}
\hline & $\begin{array}{c}\text { Normal controls } \\
\text { group }(\mathrm{N}=15)\end{array}$ & $\begin{array}{c}\text { Participants with } \\
\text { aphasia }(\mathrm{N}=15)\end{array}$ & $t$ \\
\hline Age (year) & $55.26(13.20)$ & $54.53(13.28)$ & .152 \\
Education (year) & $12.60(2.02)$ & $12.80(2.33)$ & -.250 \\
\hline
\end{tabular}

Values are presented as mean (SD).

뇌손상 병력이 보고되지 않은 자, (3) 한국형 간이정신상태검사 (Korean-Mini Mental State Examination, K-MMSE; Kang, Na, \& Hahn, 1997) 점수가 연령 및 교육연수에 비해 $16 \%$ ile 이상으로 정 상 범위에 해당하는 자, (4) SNSB-II의 하위검사인 Seoul Verbal Learning Test (SVLT)에서 점수가 연령 및 교육연수에 비해 16\%ile 이상으로 정상 범위에 해당하는 자, (5) 그 외에 언어 및 인지적 신경 학적 손상, 발달적 병력이 보고되지 않은 성인들을 대상으로 하였 다. 본 연구에 참여한 집단별 대상자의 기술통계 정보는 요약하여 Table 1에 제시하였으며 구체적인 정보는 Appendixes 1과 2에 제시 하였다. 집단별 연령과 교육연수에서 유의한 차이가 있는지 알아보 기 위해 각각 독립표본 $t$-검정(two-independent samples $t$-test)을 실시하였으며 그 결과 연령과 교육연수 모두에서 집단 간 차이가 없는 것으로 나타났다.

\section{실험자극}

이야기 주제

국외에서 IU 분석을 실시한 McNeil 등(2007)은 영어권에서 내 용이 잘 알려진 신데렐라(Cinderella) 동화를 사용하였다. 국내연 구에서는 이야기 과제로 ‘흥부와 놀부를 가장 빈번히 사용하고 있 다(Ha, Jung, \& Sim, 2009; Kim, Kim, Namkoong, Kim, \& Kim, 2006; Kim \& Sung, 2014; Jung, 2009). 따라서 본 연구에서도 ‘흥부 와 놀부' 이야기를 사용하였으며 구체적인 실험 자극은 시중에서 출판되고 있는 6 개의 동화책에 공통적으로 제시된 내용만을 포함 하여 이야기를 구성하였다. 흥부와 놀부 이야기 그림자극은 선정 한 내용에 따라 직접 제작한 그림을 사용하였다. 이야기는 1 개의 그 림당 2 문장씩 배치되도록 하였으며 이야기와 함께 총 6 장의 컬러 그림이 이야기 전개의 순서에 따라 제시되었다. 본 연구에서 사용 된 그림자극은 Appendix 3에 제시하였다.

\section{이야기 다시말하기 조건}

이야기 다시말하기는 시각 단서인 그림이 없는 청각 조건과 그림 이 있는 시각-청각 조건으로 구성되었다. 청각 조건에서는 그림 단 서가 없는 상황에서 이야기를 청각적으로만 들려주며 검은 빈 화면 이 제시되었다. 이야기가 모두 끝난 후 대상자는 그림 단서 없이 들
었던 이야기를 다시 말하도록 요청받았으며, 대상자는 다음과 같 은 지시를 받았다. “지금부터 짧은 이야기 하나를 들려드릴 것입니 다. 이야기를 잘 들으시고 이야기가 모두 끝나면 그 이야기를 저에 게 다시 말해주세요.” 시각-청각 조건에서는 이야기가 그림 단서와 함께 제시되었으며, 이야기를 다시 말할 때에도 동일한 그림 단서가 제시되었다. 대상자는 다음과 같은 지시를 받았다. "지금부터 짧은 이야기를 그림과 같이 들려드릴 것입니다. 이야기가 모두 끝난 다 음, 똑같은 그림이 다시 화면에 보여집니다. 그림을 보시면서 방금 들었던 이야기를 다시 말해주세요."

\section{연구절차}

대상자들은 2 가지의 이야기 조건에서 이야기 다시말하기를 수 행하였다. 이때 같은 이야기를 다시 사용하는 것에 대한 학습효과 를 최소화하기 위해 1 주일의 간격을 둔 후 2 회기를 실시하였다. 이 야기 다시말하기 조건의 순서는 각 대상자마다 무작위로 배치하였 으며 그 순서가 대상자 간 골고루 분포될 수 있도록 체계적으로 변 동하였다.

\section{자료분석}

IU 분석체계

$\mathrm{IU}$ 는 특정한 이야기와 관련된 적절하고 명확한 정보를 전달하 는 낱말 혹은 구를 말한다. 본래 IU에 해당하는 것은 명사, 대명사, 고유명사, 직함(title), 동사구, 형용사, 부사, 전치사, 관용어에 속하 는 숙어, 인용이 하나의 IU로 인정되나, 관사, 접속사, 보조동사는 IU에 포함되지 않는다(McNeil et al., 2001). 하지만 영어권과 달리 한국어에서는 조사가 중요한 문법적인 표지 역할을 하며 하나의 단어로 인정이 되기 때문에 본 연구에서는 Kim과 Sung (2014)에 따라 조사를 IU로 포함시키며, 접속사 또한 결속장치로써 역할을 인정하여 IU에 포함하였다. 또한 본 연구에서는 관형사도 체언에 대한 지시, 수, 성질 등을 자세히 꾸며주는 품사로써 하나의 정보를 갖고 있다고 판단하였기에 IU로 포함하였다. 본 연구에서는 McNeil 등(2001)의 IU 분석기준을 바탕으로 한국어 특성을 고려하여 적절히 수정된 IU 분석기준을 설정하였으며 자세한 분석기준은 Appendix 4에 제시하였다.

\section{IU 빈도}

IU 빈도(number of information units, \#IU)를 산출하기 위해 대 상자가 산출한 IU를 체크리스트에 기록하여 전체 IU의 빈도를 합 산하였다.

IU 빈도= 총 산출한 IU 수 
$\mathrm{IU}$ 비율

IU 비율(\%IU)을 산출하기 위해 대상자가 산출한 총 IU의 수를 체크리스트에 기록하고 전체 IU수로 나누어 백분율(\%)로 환산하 였다.

$$
\mathrm{IU} \text { 비율 }(\%)=(\text { 산출한 IU 수/총 IU 수 }) \times 100
$$

분당 IU 빈도

분당 IU 빈도(number of information units per minute, \#IU/min) 를 산출하기 위해 이야기 산출 시간을 모두 분으로 환산하였다. IU 빈도를 이야기 다시말하기에서 소요되었던 총 시간(분)으로 나누 어 산출하였다.

$$
\text { 분당 IU 빈도= 총IU 빈도/총 발화한 시간(분) }
$$

분당 IU 비율

분당 IU 비율(\%IU/min)을 산출하기 위해 이야기 산출 시간을 모두 분으로 환산하였다. IU 비율을 이야기 다시말하기에서 소요 되었던 총시간(분)으로 나누어 산출하였다.

분당 IU $(\%)=\mathrm{IU}$ 비율/총 발화한 시간(분)

\section{언어측정 변수}

실어증을 대상으로 IU와 연속발화에 따른 언어측정 변수 간의 상관관계를 살펴본 연구(McNeil et al., 2007)와 국내의 실어증 및 정상 성인을 대상으로 한 자발화 연구(Im et al., 2001; Koo \& Choi, 2015; Kwon et al., 1998)에서 공통적으로 사용한 언어측정 변수를 사용하여 본 연구의 이야기 다시말하기를 통해 산출된 발화를 분 석하였다. 우선 Lee와 Kim (2001) 분석기준에 따라 평가자가 알아 들을 수 있는 명료도를 가진 발화 내에서 살펴보았다(Glosser \& Deser, 1992). 또한 다수의 선행연구에서 발화의 의미론적 측면을 분석하기 위해 사용한 $\mathrm{CIU}$ 분석을 통해 이야기의 정보 전달량과 정보전달의 효율성을 살펴보았다. 선행연구(Kwon et al., 1998)를 바탕으로 대상자가 사용한 낱말 중 CIU 기준에 부합하는 낱말을 분석하여 CIU 수(number of correct information units, \#CIU), $\mathrm{CIU}$ 비율(percent of correct information units, \%CIU), 분당 CIU 수(number of correct information units per minute, \%CIU/min), 분당 CIU 비율(percent of correct information units per minute, $\% \mathrm{CIU} / \mathrm{min}$ )을 산출하였다. 언어측정 변수에 대한 세부적인 기준 및 산출방법은 Appendix 5에 제시하였다.

\section{통계적 처리}

자료의 통계적 처리는 SPSS version 21.0 프로그램을 이용하여
분석을 실시하였다. 시각 단서 유무(청각 vs. 시각-청각)에 따른 IU 종속 변수(\#IU, \%IU, \#IU/min, \%IU/min)에서 집단 간(실어증 집 단 vs. 정상 집단) 차이가 유의한지 분석하기 위해 이원혼합분산분 석(two-way mixed ANOVA)을 실시하였다. 또한 실어증 집단에서 이야기 다시말하기에 따른 IU 측정 변수(\#IU, \%IU, \#IU/min, \%IU/ $\mathrm{min}$ )와 기존의 언어측정 변수(발화수, 낱말 수, 분당 낱말 수, MLU$\mathrm{w}, \# \mathrm{CIU}, \% \mathrm{CIU}, \# \mathrm{CIU} / \mathrm{min}, \% \mathrm{CIU} / \mathrm{min}$ ) 간의 상관관계를 알아보 기 위해 Pearson 상관계수를 산출하였다. 마지막으로 K-WAB검사 의 하위항목(유창성, 내용전달, 알아듣기, 따라말하기, 이름대기) 및 실어증 지수(Aphasia Quotient, $\mathrm{AQ}$ )와의 상관관계를 알아보기 위해 Pearson 상관계수를 산출하였다.

\section{신뢰도}

본 연구의 이야기 다시말하기 IU 점수에 대한 신뢰도를 검증하 기 위해 평가자 간 신뢰도(inter-rater reliability)를 산출하였다. 신 뢰도는 전체 자료 중 $10 \%$ 에 해당하는 자료를 무작위로 추출하여 실시하였다. 제 1 평가자는 연구자이며 제 2 평가자는 언어병리학 석 사학위를 수료한 2 급 언어재활사이다. 제 1 평가자가 IU 채점기준에 따라 분석 및 채점을 실시하였으며 제 2 평가자는 채점기준을 숙지 한 뒤 대상자의 녹음된 파일을 듣고 독립적으로 IU를 채점하도록 하였다. 신뢰도는 평가자 간 일치한 IU 수를 총 IU 문항 수로 나누 어 백분율로 산출하였다. 그 결과 IU에 대한 평가자 간 신뢰도는 $96.7 \%$ 였다.

\section{연구결과}

\section{시각 단서에 따른 집단 간 차이분석}

시각 단서에 따른 $I U$ 빈도(\#IU) 및 IU 비율(\%IU)의 집단 간 차이 분석

시각 단서에 따른 IU 빈도 및 비율(\%)에서 집단 간차이가 있는지 분석하기 위해 각 변수에서 이원혼합분석(two-way mixed ANO$\mathrm{VA}$ )을 실시하였으며 그 결과는 Figures 1, 2에 제시하였다. 또한 각 집단별 IU 빈도 및 비율(\%)에 따른 기술통계 결과는 Table 2에 제 시하였다.

시각 단서에 따른 IU 빈도에서 집단 간 차이가 유의한지 분석하기 위해 이원혼합분산분석(two-way mixed ANOVA)을 실시한 결과 (Figure 1), 집단 간 주효과가 통계적으로 유의하였다 $\left(F_{(1,28)}=69.240\right.$, $p<.001)$. 즉, 실어증 집단의 IU 빈도가 정상 집단의 IU 빈도보다 유 의하게 낮은 것으로 나타났다. 시각 단서에 대한 주효과도 통계적 으로 유의하였다 $\left(F_{(1,28)}=7.127, p<.05\right)$. 즉, 청각 조건에 비해 시각청각 조건에서 IU 빈도가 유의하게 높았다. 반면, 시각 단서에 따른 


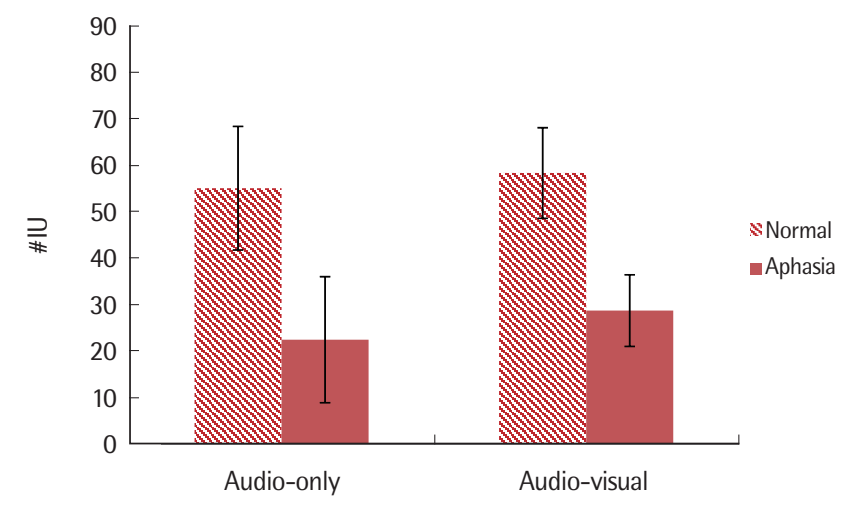

Figure 1. Number of information unit (\#IU) in story retelling tasks depending on the visual cues for each group.

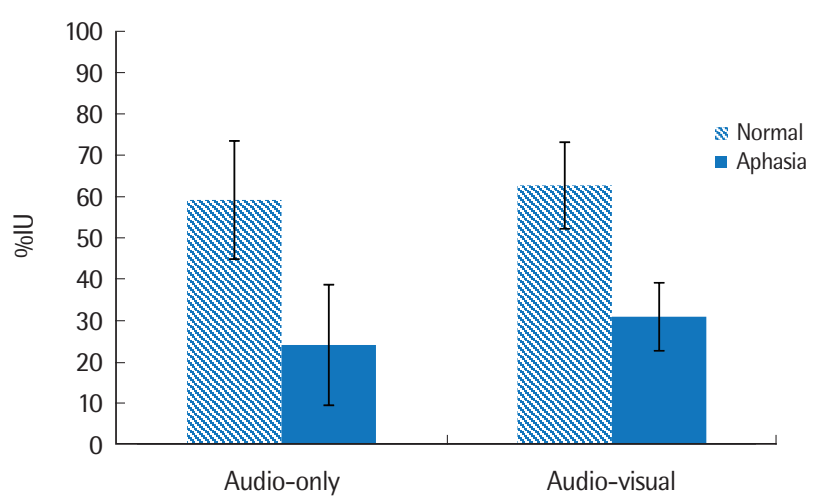

Figure 2. Percent of information unit (\%lU) in story retelling tasks depending on the visual cues for each group.

Table 2. Descriptive statistics of number of IU and percent of IU for each condition in both normal and aphasic groups

\begin{tabular}{lccc}
\hline Group & Condition & Number of IU & Percent of IU \\
\hline Normal & AO & $55.00 \pm 12.84(36-80)$ & $59.13 \pm 13.80(38.70-86.02)$ \\
$(\mathrm{N}=15)$ & AV & $58.26 \pm 9.41(42-72)$ & $62.64 \pm 10.12(45.16-77.41)$ \\
Aphasia & AO & $22.40 \pm 13.10(6-48)$ & $24.08 \pm 14.08(6.45-51.61)$ \\
$(\mathrm{N}=15)$ & AV & $28.67 \pm 7.44(16-42)$ & $30.91 \pm 7.94(17.20-45.16)$ \\
\hline
\end{tabular}

Values are presented as mean $\pm S D$ (range).

$A O=$ auditory only condition; $A V=$ auditory visual condition; $I U$ = information unit.

집단 간 이차 상호작용은 유의하지 않았다 $\left(F_{(1,28)}=.706, p>.05\right)$.

시각 단서에 따른 IU 비율에서 집단 간 차이가 유의한지 분석하 기 위해 이원혼합분산분석(two-way mixed ANOVA)을 실시한 결 과(Figure 2), 집단간주 효과가 통계적으로 유의하였다 $\left(F_{(1,28)}=69.198\right.$, $p<.001)$. 즉, 실어증 집단의 IU 비율이 정상 집단의 IU 비율보다 유 의하게 낮은 것으로 나타났다. 시각 단서에 대한 주 효과도 통계적 으로 유의하였다 $\left(F_{(1,28)}=7.256, p<.05\right)$. 즉, 청각 조건에 비해 시각청각 조건에서 IU 비율이 유의하게 높았다. 반면, 시각 단서에 따른

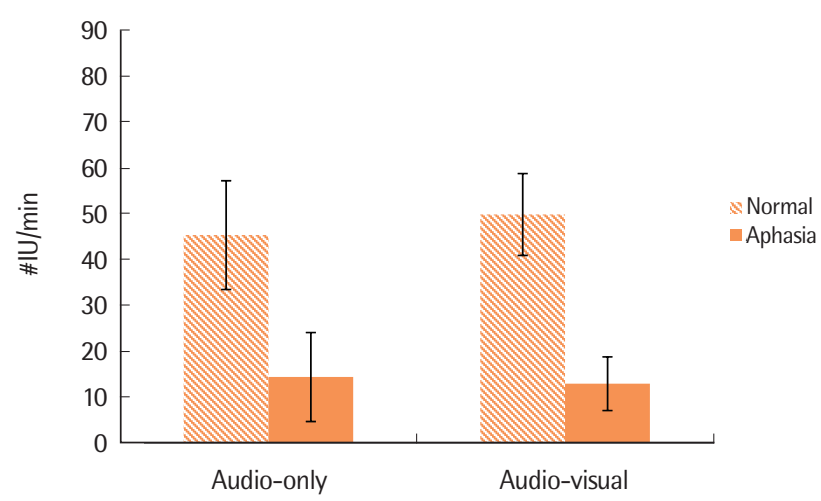

Figure 3. Number of information unit per minute (\#IU/min) in story retelling tasks depending on the visual cues for each group.

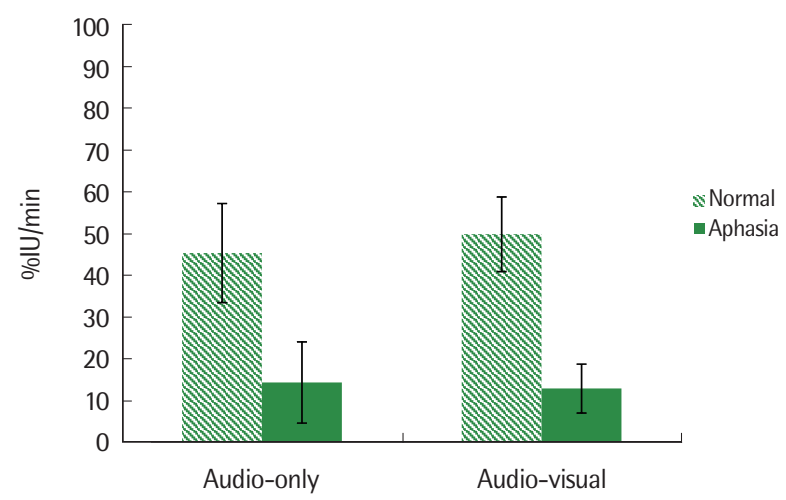

Figure 4. Percent of information unit per minute $(\% \mathrm{lU} / \mathrm{min})$ in story retelling tasks depending on the visual cues for each group.

Table 3. Descriptive statistics of number of IU per minute and percent of IU per minute for each condition in both normal and aphasic groups

\begin{tabular}{lccc}
\hline Group & Condition & Number of IU per minute & Percent of IU per minute \\
\hline Normal & AO & $45.29 \pm 11.46(24.43-66.28)$ & $49.42 \pm 11.95(26.27-71.67)$ \\
$(\mathrm{N}=15)$ & AV & $49.80 \pm 8.63(34.97-66.67)$ & $53.71 \pm 9.63(37.60-73.84)$ \\
Aphasia & AO & $14.32 \pm 9.38(2.44-24.00)$ & $15.39 \pm 10.09(2.62-35.18)$ \\
$(\mathrm{N}=15)$ & AV & $12.86 \pm 5.66(6.37-27.43)$ & $13.58 \pm 6.16(6.85-29.46)$ \\
\hline
\end{tabular}

Values are presented as mean $\pm S D$ (range).

$A O=$ auditory only condition; $A V=$ auditory visual condition; $I U=$ information unit.

집단 간 이차 상호작용은 유의하지 않았다 $\left(F_{(1,28)}=.746, p>.05\right)$.

시각 단서에 따른 분당 $\| \cup$ 빈도(\#॥ $/ \mathrm{min})$ 및 분당 $U$ 비율(\%IU/min)의 집단 간 차이 분석

시각 단서에 따른 분당 IU 빈도 및 비율(\%)에서 집단 간 차이가 있는지 분석하기 위해 각 변수에서 이원혼합분석(two-way mixed ANOVA)을 실시하였으며 그 결과는 Figures 3 과 4에 제시하였다. 또한 각 집단별 분당 IU 빈도 및 비율(\%)에 따른 기술통계 결과는 
Table 3에 제시하였다.

시각 단서에 따른 분당 IU 빈도에서 집단 간 유의한 차이가 있는 지 분석하기 위해 이원혼합분석(two-way mixed ANOVA)을 실시 하였으며 그 결과(Figure 3), 집단 간 주 효과가 통계적으로 유의하 였다 $\left(F_{(1,28)}=100.396, p<.001\right)$. 즉, 실어증 집단이 정상 집단에 비해 분당 IU 비율이 유의하게 낮은 것으로 나타났다. 반면 시각 단서에 대한 주 효과는 통계적으로 유의하지 않았다 $\left(F_{(1,28)}=.638, p>.05\right)$. 또한 시각 단서에 따른 집단 간 이차 상호작용도 유의하지 않았다 $\left(F_{(1,28)}=2.445, p>.05\right)$.

시각 단서에 따른 분당 IU 비율에서 집단 간 유의한 차이가 있는 지 분석하기 위해 이원혼합분산분석(two-way mixed ANOVA)을 실시한 결과(Figure 4), 집단 간 주 효과가 통계적으로 유의하였다 $\left(F_{(1,28)}=100.396, p<.001\right)$, 즉, 실어증 집단이 정상 집단에 비해 분 당 IU 비율이 유의하게 낮은 것으로 나타났다. 반면 시각 단서에 대 한 주 효과는 통계적으로 유의하지 않았다 $\left(F_{(1,28)}=.349, p>.05\right)$. 또 한 시각 단서에 따른 집단 간 이차 상호작용도 유의하지 않았다 $\left(F_{(1,28)}=2.094, p>.05\right)$.

\section{시각 단서에 따른 IU 산출과 언어측정 변수 간의 상관관계}

시각 단서에 따른 IU 산출과 언어측정 변수(발화 수, 낱말 수, 분 당 낱말 수, MLU-w, CIU 수, CIU 비율, 분당 CIU 수, 분당 CIU 비
율) 간의 상관관계를 살펴보기 위해 실어증 집단을 대상으로 Pearson 상관계수를 산출하였다.

청각 조건에서 IU와 언어측정 변수 간의 상관관계를 분석한 결 과(Table 4), IU 빈도의 경우 발화 수, 낱말 수, $\mathrm{CIU}$ 수, 분당 CIU 수 와 유의한 상관관계를 보였으며 그 범위는 $r=.567-.870$ 이었다. IU 비율 역시 발화 수, 낱말 수, $\mathrm{CIU}$ 수, 분당 CIU 수와 유의한 상관관 계를 보였으며 그 범위는 $r=.567-.870$ 이었다. 또한 분당 IU 빈도의 경우, 분당 낱말 수, $\mathrm{CIU}$ 비율, 분당 $\mathrm{CIU}$ 비율과 유의한 상관관계를 보였고 그 범위는 $r=.555-.885$ 이었다. 분당 IU 비율 역시 분당 낱말 수, $\mathrm{CIU}$ 비율, 분당 $\mathrm{CIU}$ 비율과 유의한 상관관계를 보였고 그 범위 는 $r=.555-.885$ 이었다.

시각-청각 조건에서 IU와 언어측정 변수 간의 상관관계를 분석 한 결과(Table 5), IU 빈도의 경우 발화 수, 낱말 수, CIU 수와 유의 한 상관관계를 보였으며 그 범위는 $r=.526-.718$ 이었다. IU 비율에 서는 발화수, 낱말 수, $\mathrm{CIU}$ 수와 유의한 상관관계를 보였으며 그 범 위는 $r=.538-.721$ 이었다. 또한 분당 IU 빈도의 경우, 분당 낱말 수, $\mathrm{CIU}$ 비율, 분당 $\mathrm{CIU}$ 비율과 유의한 상관관계를 보였고 그 범위는 $r=.676-.884$ 이었다. 분당 IU 비율에서는 분당 낱말 수, CIU 비율, 분당 $\mathrm{CIU}$ 비율과 유의한 상관관계를 보였고 그 범위는 $r=.659$ .854 이었다.

Table 4. Correlation coefficients among IU measures and linguistic variables in the audio-only condition

\begin{tabular}{lcccccccc}
\hline IU measures & \#utterance & \#word & \#word/min & MLU-w & \#CIU & \%CIU & \#CIU/min & \%CIU/min \\
\hline \#IU & $.658^{* *}$ & $.653^{*}$ & -.124 & .161 & $.870^{* *}$ & .121 & $.567^{*}$ & -.158 \\
\%IU & $.658^{* *}$ & $.635^{*}$ & -.124 & .161 & $.870^{* *}$ & .121 & $.567^{*}$ & -.158 \\
\#IU/min & -.491 & -.446 & $.555^{*}$ & -.043 & -.140 & $.768^{* *}$ & $.500^{*}$ & $.885^{* *}$ \\
\%IU/min & -.491 & -.446 & $.555^{*}$ & -.043 & -.140 & $.768^{* *}$ & $.500^{*}$ & $.885^{* *}$ \\
\hline
\end{tabular}

$\# \mathrm{U}=$ = number of information units; \% $\mathrm{IU}=$ percent of information units; \#IU/min= number of information units per minute; \% $\mathrm{IU} / \mathrm{min}=$ percent of Information units per minute; \#utterance = number of utterances; \# word = number of words; \#word/min= number of words per minute; MLU-w= mean length of utterance-in words; \#CIU=number of correct information units; \%CIU = percent of correct information units; \#CIU/min= number of correct information units per minute; \%CIU/min= percent of correct information units per minute.

${ }^{*} p<.05,{ }^{* *} p<.001$.

Table 5. Correlation coefficients among IU measures and linguistic variables in the audio-visual condition

\begin{tabular}{lcccccccc}
\hline IU measures & \#utterance & \#word & \#word/min & MLU-w & \#CIU & \%CIU & \#CIU/min & \%CIU/min \\
\hline \#IU & $.610^{*}$ & $.526^{*}$ & .120 & -.279 & $.718^{* *}$ & .241 & .151 & -.053 \\
\%IU & $.620^{*}$ & $.538^{*}$ & .122 & -.278 & $.721^{* *}$ & .236 & .130 \\
\#IU/min & -.288 & -.226 & $.676^{* *}$ & .231 & -.057 & $.884^{* *}$ & .405 \\
\%IU/min & -.301 & -.224 & $.659^{* *}$ & .264 & -.074 & $.854^{* *}$ & .387 & $.868^{* *}$ \\
\hline
\end{tabular}

$\# \mid \mathrm{U}=$ number of information units; \% $\%=$ percent of information units; \#IU/min= number of information units per minute; \%lU/min=percent of Information units per minute; \#utterance = number of utterances; \#word = number of words; \#word/min= number of words per minute; MLU-w= mean length of utterance-in words; \#CIU= number of correct information units; \% CIU = percent of correct information units; \#CIU/min= number of correct information units per minute; \%CIU/min= percent of correct information units per minute.

${ }^{*} p<.05,{ }^{* *} p<.001$. 
Table 6. Correlation coefficients among IU measures, $A Q$, and the subtests of $K$-WAB depending on the visual cues

\begin{tabular}{|c|c|c|c|c|c|c|c|}
\hline Condition & IU measures & $\mathrm{A} 0$ & Fluency & Contents & Comprehension & Repetition & Naming \\
\hline \multirow[t]{4}{*}{$\mathrm{AO}$} & $\# I U$ & .382 & .230 & .364 & .200 & .147 & $.596^{*}$ \\
\hline & $\%$ & .382 & .230 & .364 & .200 & .147 & $.596^{*}$ \\
\hline & $\# \mathrm{U} / \mathrm{min}$ & $.619^{*}$ & $.673^{* *}$ & .285 & .428 & $.562^{*}$ & .272 \\
\hline & $\% \| l$ min & $.619^{*}$ & $.673^{* *}$ & .285 & .428 & $.562^{*}$ & .272 \\
\hline \multirow[t]{4}{*}{ AV } & $\# U$ & .325 & .226 & .196 & .131 & -.065 & $.682^{* *}$ \\
\hline & $\%$ & .309 & .209 & .178 & .139 & -.070 & $.658^{* *}$ \\
\hline & \#IU/min & .487 & $.531^{*}$ & .323 & .097 & .395 & .338 \\
\hline & $\%$ IU/min & .455 & .483 & .381 & .047 & .357 & .335 \\
\hline
\end{tabular}

$I U=$ information unit; $A Q=$ Aphasia Quotient (K-WAB); K-WAB=Korean Version-Western Aphasia Battery (Kim \& Na, 2001); $A 0=$ auditory only condition; $A V=$ auditory visual condition; \#IU=number of information units; \% $\mathrm{lU}=$ percent of information units; \#IU/min= number of information units per minute; \% $\% / \mathrm{U} / \mathrm{min}=$ percent of information units per minute. ${ }^{*} p<.05,{ }^{* *} p<.001$.

\section{IU와 실어증 환자의 중증도(AQ) 및 실어증검사의 하위항목 간의 상관관계}

실어증 집단을 대상으로 시각 단서에 따른 IU 산출과 중증도 (AQ) 및 실어증검사의 하위항목(유창성, 내용전달, 알아듣기, 따라 말하기, 이름대기) 간의 상관관계를 살펴보기 위해 Pearson 상관계 수를 산출하였으며 그 결과는 Table 6에 제시하였다.

청각 조건에서 IU와 중증도( $\mathrm{AQ})$ 및 $\mathrm{K}-\mathrm{WAB}$ 의 하위항목 간의 상관관계를 분석한 결과, IU 빈도 및 비율 모두 이름대기와 상관관 계를 보였다 $(r=.596)$. 분당 IU 빈도에서는 $\mathrm{AQ}$, 유창성, 따라말하기 와 유의한 상관관계를 보였으며 그 범위는 $r=.562-.673$ 이었다. 분 당 IU 비율 역시 $\mathrm{AQ}$, 유창성, 따라말하기와 유의한 상관관계를 보 였으며 그 범위는 $r=.562-673$ 이었다.

시각-청각 조건에서 IU와 중증도(AQ) 및 K-WAB의 하위항목 간 상관관계를 분석한 결과, $\mathrm{IU}$ 빈도 및 비율 모두 이름대기와상관 관계를 보였으며 그 범위는 $r=.658-682$ 이었다. 분당 IU 빈도에서 는 유창성과 유의한 상관관계를 보였다 $(r=.531)$. 반면 분당 IU 비 율은 $\mathrm{AQ}$ 와 검사의 하위항목 모두에서 유의한 상관관계가 나타나 지 않았다 $(p>$.05).

\section{논의 및 결론}

이야기 다시말하기 과제는 실어증 환자의 언어능력을 파악하는 데 유용한 방법으로써 환자의 수행력에 대한 다양한 정보를 제공 할 수 있다. 하지만 아직까지 국내연구에서는 시각 단서에 따른 이 야기 다시말하기 수행을 비교한 연구는 찾아보기 힘들다. 또한 한 국 실어증 환자를 대상으로 IU 분석방법을 적용하는 것에 대한 유 용성 및 타당성 연구는 전무한 실정이다. 따라서 본 연구의 목적은 $\mathrm{IU}$ 분석을 활용하여 시각 단서 유무에 따른 실어증 환자의 이야기
다시말하기 수행을 비교하며, 각 조건에서 사용된 IU 분석의 유용 성을 확인하기 위해 기존의 언어측정 변수와 실어증 중증도 및 표 준화된 검사도구 간의 상관관계를 살펴보는 것이다.

우선 IU 빈도 및 비율에서 집단에 대한 주 효과가 통계적으로 유 의하였다. 즉, 실어증 집단이 정상 집단에 비해 IU 산출이 저조하였 다. 이러한 결과는 IU 분석방법이 정상 집단으로부터 실어증 집단 을 변별하는 데 신뢰롭고 타당한 측정 방법이라고 주장한 기존의 선행 연구 결과와 일치한다(McNeil et al., 2001). 또한 IU 빈도 및 비율에서 시각 단서 유무에 대한 주 효과 또한 통계적으로 유의하 였다. 실어증 집단과 정상 집단 모두 시각 단서가 없는 청각 조건에 비해 시각 단서가 제시되는 시각-청각 조건에서 IU 산출이 유의미 하게 증가하였다. 이는 결과적으로 실어증 환자들이 단서를 제공받 았을 때 언어표현에서 상당히 도움을 받는다고 한 선행연구의 결과 와 맥락을 같이 하는 부분이다(Doyle et al., 1998). 또한 Doyle 등 (2000)에서도 이야기 다시말하기 과제에서 그림 자극을 동시에 제 공하는 방법은 이해력 및 자극 내용의 재구성에 도움을 주며, 언어 기억력에 대한 인지적 요구를 감소시켜주는 효과가 있다고 보고하 였다. 이와 같이 본 연구는 시각 단서인 그림 자극을 제공하는 경우 환자의 수행력이 향상될 수 있다고 설명한 기존 연구결과와 일치한 다. 반면, 시각 단서에 따른 집단 간 상호작용효과는 통계적으로 유 의하지 않았다. 즉, 시각적 단서 유무에 따라 집단 간 차이가 유의하 지 않았다. 이러한 상호작용의 부재는 시각적 단서 제공에 따른 수 행력 증가 효과가 실어증 환자에게만 더 크게 나타난 것은 아니었 음을 시사한다. 이러한 결과에 따르면, 시각적 단서 효과 자체가 실 어증 환자에게만 특정적으로 나타나는 요인은 아닐 수 있으며, 정 상군 및 실어증 환자군 모두에서 이야기 다시말하기의 수행력을 상승시키는 요인으로 작용한 것으로 해석된다. 실어증 환자군을 대 상으로 보다 다양한 언어 및 비언어적 단서 연구를 통해 실어증 환 
자에게 특별히 더 효과적인 변수를 알아보는 연구들이 다양하게 이루어질 필요가 있다.

시간적인 효율성 측면이 반영된 분당 IU 빈도 및 비율에서 집단 에 대한 주 효과만 통계적으로 유의하였다. 즉, 실어증 집단의 분당 $\mathrm{IU}$ 산출이 정상 집단의 분당 IU 산출에 비해 유의하게 낮은 것으 로 나타났다. 이는 분당 IU 비율이 실어증 집단을 정상 집단으로부 터 변별해내는 민감한 지표라는 영어권 선행연구와 일치하는 결과 이다(McNeil et al., 2002). 반면, 시각 단서에 대한주 효과는 통계적 으로 유의하지 않았으며 이차상호작용 또한 통계적으로 유의하지 않았다. IU 빈도 및 비율에서는 단서 유무에 따른 주 효과가 유의하 였던 것에 비해 시간을 분모로 표준화한(normalized by time) 분당 IU 빈도 및 비율에서는 단서에 대한 주 효과가 유의하지 않았음은 다음과 같이 해석할 수 있다. 양적 지표로써 빈도 및 비율은 시각 단서가 제시될 때 발화량이 유의하게 증가하는 것과 비례하여 발 화시간 또한 증가하게 된다. 하지만, 발화시간을 분모로 표준화하 는 효율성 지표의 경우, 발화시간이 길어지는 것에 비해 발화량이 유의하게 증가하지 않으며 이는 시각 단서가 주어지는 조건임에도 불구하고 충분히 도움을 받지 못한 것에 기인한다. 즉, 시각 단서 유 무에 따른 이야기 다시말하기를 비교한 결과 두 집단 모두 IU 산출 이 증가하였으나 IU 산출방식에 따라 다른 결과를 보였다. 이러한 결과는 빈도 산출이라는 양적 변수를 사용할 때와 시간에 따른 발 화량 증가분을 계산하는 효율성 측면이 반영된 변수로 측정할 경 우, 다소 상이한 결과를 초래할 수 있음을 보여준다. 이는, 실어증 환자의 발화 분석 및 해석에 있어, 언어측정 변수의 산출 방식을 다 양화 할 필요가 있으며, 이에 따른 적절한 해석과 상호보완적인 적 용이 필요함을 시사한다.

실어증 집단에서 IU 산출과 기존의 발화 분석에서 사용된 언어 측정 변수 간의 상관관계를 살펴본 결과, 변수 간 높은 상관도를 보 였다. 청각 조건에서 그 결과를 살펴보면, IU 빈도 및 비율(\%)에서 는 발화 수, 낱말 수, $\mathrm{CIU}$ 수, 분당 $\mathrm{CIU}$ 수와 비교적 강한 정적 상관 관계 $(r=.635-870)$ 를 보였다. 이는 기존의 의미론적 측면을 반영하 는 정보 전달의 양과 관련된 변수 간에 관련성이 높음을 보여주는 결과이다. 반면, IU 빈도 및 비율과 관련된 변수와 분당 낱말 수, 발 화당 낱말 수(MLU-w), CIU 비율, 분당 CIU 비율은 상관관계가 유 의하지 않았다. 이는 양적 변수에 해당하는 IU 빈도 및 비율 관련 변수와 발화의 효율성을 대표할 수 있는 변수 간의 관련성은 상대 적으로 낮게 나타났음을 시사한다. 즉, 의미적 정보 전달이라는 공 통점을 가지고 있는 양적 변수 간 관련성이 크게 나타났으며, 정보 전달의 산출 방식(양적 vs. 효율성)에 따라 변수 간 상관관계가 달 라질 수 있음을 의미한다.
발화시간을 표준화하여 발화의 효율성 측면을 살펴볼 수 있는 분당 IU 빈도 및 비율(\%)에서는 청각 조건과 시각-청각 조건 모두 에서 정보 전달의 효율적인 측면을 나타내는 분당 낱말 수, CIU 비 율, 분당 CIU 비율과 상관관계 $(r=.555-885)$ 가 유의한 것으로 나타 났다. 이는 분당 IU 비율(\%)이 이야기 다시 말하기 과제 내의 분당 낱말 수 및 $\mathrm{CIU}$ 측정 변수와(CIU 수, $\mathrm{CIU}$ 비율, 분당 $\mathrm{CIU}$ 수)의 상 관관계가 높았다고 보고한 선행연구(McNeil et al., 2007)의 결과와 일치한다. 반면, 두 가지 조건 모두에서 분당 IU 빈도 및 비율(\%)과 발화 수, 낱말 수, 발화당 낱말 수(MLU-w), CIU 수와는 상관관계 가 유의하지 않았다. 이는 발화의 효율성을 측정하는 변수들은 양 적 분석에 기반을 둔 언어측정 변수와는 비교적 상관관계가 낮다 는 것을 시사한다. 또한 IU 측정 변수들과 발화 당 낱말 수(MLU$\mathrm{w})$ 와의 상관계수는 유의하지 않았는데, 이는 IU 분석체계가 기존 의 자발화 분석에서 통사적인 측면을 살펴보는 변수와는 관련성이 낮을 수 있음을 의미한다. IU 분석에서 영어권 분석 기준과는 달 리, 한국어 특징을 반영하여 조사를 하나의 독립적인 IU로 분석에 포함하였으나 조사만으로는 통사적인 측면의 다양한 척도를 가늠 하기에는 한계가 있는 것으로 보인다. 이러한 결과에 따르면, 실어 증 환자의 자발화 분석 시, 의미 및 통사적 측면 등의 다양한 변수 를 분석하기 위해서는 통사적인 측면에서의 문장 분석이 추가적으 로 병행되는 것이 필요함을 알 수 있다. 하지만 기존의 의미론적 측 면을 측정하는 $\mathrm{CIU}$ 수와 분당 $\mathrm{CIU}$ 수와 가장 높은 상관관계를 보 였다는 점에서, IU 분석체계의 장점은 발화를 직접 전사하지 않아 도 기존의 의미론적인 요소들을 IU 체크리스트를 사용하여 효율 적으로 측정할 수 있다는 것이다. 이는 임상에서 빠른 시간에 정보 관련 변수들의 분석이 가능한 유용한 측정 변수로 사용될 수 있음 을 시사한다.

실어증 집단에서 $\mathrm{IU}$ 산출과 중증도(AQ) 및 실어증 검사 하위항 목 간의 상관관계를 살펴보았다. 그 결과, 그림이 제시되는 시각-청 각 조건에 비해 그림이 제시되지 않는 청각 조건에서 중증도(AQ) 와 더 많은 하위 항목(유창성, 따라말하기, 이름대기)과의 상관관계 가 나타났다. 이러한 결과는 시각 단서가 주어지지 않는 조건에서 언어능력에 대한 요구가 더 많았다는 것을 의미한다. 선행연구 Stark (2010)에서는 내용을 잘 알고 있는 동화와 같은 이야기 담화를 재산 출 하는 것은 다양한 처리 요소들과 복합적인 언어적 수준의 상호 작용이 요구되는 과제라고 설명하였다. 즉, 장기기억 속에 있던 전래 동화의 내용을 회상하여 유지하는 동시에 언어적으로 적절한 단어 혹은 구문을 선택하여 문장을 산출해야 하는 일련의 과정에서 더 다양한 언어적 능력을 필요로 한 것이다. IU 분석과 각 변수들 간의 구체적인 상관관계의 결과를 살펴보면 다음과 같다. IU 빈도 및 비 
율(\%)에서는 시각 단서와 상관없이 모든 조건에서 이름대기만 높 은 상관관계를 보였으며 중증도(AQ)와 그 외의 변수(유창성, 내용 전달, 알아듣기, 따라말하기)에서는 상관도가 유의하지 않았다. IU 와 이름대기가 높은 상관관계를 보인 것은 이야기에서 출현한 단어 를 재인하는 과정을 반영하는 IU 측정 기준과 연관된다. 하지만 IU 산출과 유창성 간의 상관성은 유의하지 않은 것으로 나타났다. 이 는 단순히 의미 정보 단위의 산출 빈도만을 반영하는 IU 빈도 및 비 율 측정 변수는 발화유창성과 관련이 낮은 것으로 보인다.

반면, 발화의 시간적 측면을 반영한 분당 IU 빈도 및 비율(\%)에 서는 중증도(AQ), 유창성, 따라말하기가 청각 조건에서 상관관계 가 높게 나타났으며, 시각-청각 조건에서는 유창성만 상관관계가 유의하였다. 즉, 두 조건 모두 분당 IU 산출이 유창성과 상관관계가 있는 것으로 나타났다. 발화시간을 표준화한 IU 측정 변수들과 유 창성 간 관련성을 입증한 결과는 IU 분석이 직접 발화를 전사하는 것이 아님에도 불구하고 임상적으로 유용한 발화 유창성을 반영할 수 있는 측정 변수가 될 수 있음을 시사한다. 유창성 변수와는 달리 따라말하기 변수의 경우, 그림 조건이 제시되지 않은 청각 조건에 서만 분당 IU 빈도 및 비율(\%)과 상관관계가 유의한 것으로 나타났 다. 이는 들었던 내용을 기억하여 입력하는 동시에 산출을 요구하 는 따라말하기 과제의 특성에 기인한 것으로 보인다. 그림 단서가 없는 이야기 다시말하기 조건에서는 들었던 이야기 내용을 활성화 시켜 말해야 하기 때문에 따라말하기 능력과 관련성이 높은 것으 로 나타난 것으로 해석된다. 반면, 상대적으로 그림 단서가 주어지 는 시-청각 조건에서는 시각 단서로 인해 청각적으로 활성화하여 인출해야 하는 부담이 적어 관련성이 낮게 나타난 것으로 보인다. 또한 $\mathrm{AQ}$ 로 대표되는 중증도가 분당 IU 산출에서 단서가 제시되지 않은 청각 조건에서만 상관관계가 나타났다. 이는 과제에 대해 언 어 및 인지적 요구가 많아지는 조건일수록 실어증 환자의 중증도가 수행에 영향을 미칠 수 있다는 것을 의미한다. 하지만 단서가 제공 되는 이야기 조건에서는 중증도에 따른 IU 상관도가 떨어졌다. 다 시 말해, 그림 단서가 없는 조건에서는 환자의 수행력에 중증도가 영향을 미치는 것으로 나타났으며 그림 단서가 주어진 조건에서는 그 중증도에 대한 영향이 상대적으로 약화될 수 있음을 알 수 있다. 이는 과제 수행에 있어서 실어증 환자 간의 중증도에 따른 수행력 의 차이를 좁히는 데 단서 활용이 환자에게 도움이 될 수 있음을 시 사한다.

본 연구에서는 정상 집단과 실어증 집단 모두 시각 단서를 제공 받았을 때 이야기 산출에 더 많은 도움을 받는 것으로 나타났으며 시각 단서의 유무가 환자의 언어 표현에 영향을 미칠 수 있음을 확 인할 수 있었다. 또한 IU 분석이 기존의 발화 전사를 통한 기존의
언어측정 변수들과 관련이 높았으며 새로운 측정 변수로 활용될 수 있다는 점을 밝혔다. 다시 말해, 본 연구의 결과들은 발화를 직 접 전사하는 방법에 비해 체크리스트를 활용한다는 측면에서 IU 가 임상적으로 유용성이 높은 언어능력 측정 변수라는 점을 밝힌 연구라는 점에서 의의를 가진다. 단, 본 연구에 참여한 실어증 환자 는 대부분 경도(mild)에서 중도(moderate)의 중증도를 보이며 경 도(mild) 수준에서 진단되는 명칭실어증(anomic aphasia)과 비교 적 따라 말하기가 가능한 연결피질운동실어증(transcortical motor aphasia)으로 제한되어 있다. 이는 다양한 언어 및 산출 능력을 요구하는 과제의 특성상 경중도의 유창형 실어증 환자에게 주로 이야기 다시말하기가 가능했기 때문이다. 또한 IU 산출과 환자의 유창성 간의 상관관계가 유의하였으며, $\mathrm{IU}$ 산출이 $\mathrm{AQ}$ 로 산출되는 중증도와도 상관관계가 나타났다. 이런 점들을 미루어 보았을 때, $\mathrm{IU}$ 분석체계에 대한 적용은 실어증 환자의 중증도나 유형에 따라 적절한 사용이 필요하다는 것을 시사하고 있다. 향후 연구에서는 보다 다양한 실어증 중중도 및 유형에 적용하여, IU 분석체계를 가 장 적절하게 적용할 수 있는 실어증 환자군을 찾아보는 노력이 필 요할 것으로 보인다.

본 연구의 제한점 및 후속 연구에 대한 제언은 다음과 같다. 우 선, 이야기 다시말하기 과제에서 시각 단서인 그림자극의 유무에 따른 수행결과만을 비교해 보았다. 후속 연구에서는 실어증 환자의 이야기 다시말하기에 영향을 줄 수 있는 다양한 수준으로 단서를 조절하여 비교·분석한다면 실어증 환자의 평가 및 중재에 도움이 되는 연구가 될 것이다. 또한 본 연구에서는 이야기 다시말하기 과 제라는 단일 과제만을 통해 IU의 유용성을 분석하였다는 측면에 서 한계가 있다. 향후 연구에서는 다양한 발화 수집 과제를 사용하 여 IU 분석체계의 임상적 효율성과 유용성을 검증할 필요가 있다. 또한, 실어증 환자 외에 다양한 언어장애 집단을 대상으로 지속적 인 IU 분석방법에 대한 신뢰도 및 타당도 연구가 뒷받침되어야 할 것으로 생각된다.

\section{REFERENCES}

Azuma, T., \& Bayles, K. A. (1997). Memory impairments underlying language difficulties in dementia. Topics in Language Disorders, 18, 58-71.

Bayles, K. A., \& Boone, D. R. (1982). The potential of language tasks for identifying senile dementia. Journal of Speech and Hearing Disorders, 47, 210217.

Brodsky, M. B., McNeil, M. R., Doyle, P. J., Fossett, T. R., Timm, N. H., \& Park, G. H. (2003). Auditory serial position effects in story retelling for non-brain- 
injured participants and persons with aphasia. Journal of Speech, Language, and Hearing Research, 46, 1124-1137.

Christensen, K. J., Multhaup, K. S., Nordstrom, S., \& Voss, K. (1991). A cognitive battery for dementia: development and measurement characteristics. Psychological Assessment: A Journal of Consulting and Clinical Psychology, 3, 168-174.

Darley, F. L., Aronson, A. E., \& Brown, J. R. (1975). Motor speech disorders. Philadelphia, PA: W. B. Saunders.

Doyle, P. J., McNeil, M. R., Park, G., Goda, A., Rubenstein, E., Spencer, K., \& Szwarc, L. (2000). Linguistic validation of four parallel forms of a story retelling procedure. Aphasiology, 14, 537-549.

Doyle, P. J., McNeil, M. R., Spencer, K. A., Goda, A. J., Cottrell, K., \& Lustig, A. P. (1998). The effects of concurrent picture presentations on retelling of orally presented stories by adults with aphasia. Aphasiology, 12, 561-574.

Duffy, J. R. (2005). Motor speech disorders: substrates, differential diagnosis and management (2nd ed.). New York, NY: Mosby.

Gazella, J., \& Stockman, I. J. (2003). Children's story retelling under different modality and task conditions implications for standardizing language sampling procedures. American Journal of Speech-Language Pathology, 12, 6172.

Glosser, G., \& Deser, T. (1992). A comparison of changes in macrolinguistic and microlinguistic aspects of discourse production in normal aging. Journal of Gerontology, 47, 266-272.

Ha, J. W., Jung, Y. H., \& Sim, H. S. (2009). The functional characteristics of fillers in the utterances of dementia of Alzheimer's type, questionable dementia, and normal elders. Communication Sciences \& Disorders, 14, 514530.

Hula, W., McNeil, M., Doyle, P., Rubinsky, H., \& Fossett, T. (2003). The interrater reliability of the story retell procedure. Aphasiology, 17, 523-528.

Im, E. J., Kwon, M., \& Sim, H. S. (2001). The informativeness and efficiency of the connected speech samples in Korean fluent aphasia. Communication Sciences \& Disorders, 6, 374-391.

Jung, Y. H. (2009). A study for the informativeness and efficiency of spontaneous speech depending on task type in patients with Alzheimer's disease (Master's thesis). Ewha Womans University, Seoul, Korea.

Kang, Y., Jang, S. M., \& Na, D. L (2012). Seoul Neuropsychological Screening Battery (2nd ed.). Seoul: Human Brain Research \& Consulting.

Kang, Y., Na, D. L., \& Hahn, S. (1997). A validity study on the Korean MiniMental State Examination (K-MMSE) in dementia patients. Journal of the Korean Neurological Association, 15, 300-308.
Karri, K. S., Lynn, M., Maher, H. A., Swearengin, F. F., Singletary, L. J., \& Gonzalez, R. (2002). Impact of different stimulus attributes on narrative discourse in aphasia. The ASHR Leader, 182, 13-15.

Kim, H. H. (1996). Perceptual, acoustical, and physiological tools in ataxic dysarthria management: a case report. Proceedings on the 2nd Conference in the Korean Society of Phonetic Sciences and Speech Technology Semiannual, 9-22.

Kim, H. H., \& Na, D. L. (2001). Paradise-Korean version-Western Aphasia Battery ( $K$-WAB). Seoul: Paradise Welfare Foundation.

Kim, H. N. (2014). Concurrent validity of Information Unit scoring system for individuals with mild cognitive impairment (Master's thesis). Ewha Womans University, Seoul, Korea.

Kim, H. N., \& Sung, J. E. (2014). Age-related changes in story retelling procedures and their relation to working memory capacity. Special Education Research, 13, 7-24.

Kim, J., Kim, H., Namkoong, K., Kim, S., \& Kim, D. (2006). Spontaneous speech traits in patients with Alzheimer's disease. Korean Journal of Communication \& Disorders, 11, 82-98.

Kim, Y. T. (2002). Diagnosis and treatment of language disorders in children. Seoul: Hakjisa.

Koo, S., \& Choi, H. (2015). Characteristics of spontaneous speech in Broca’s aphasic patients through interview and picture description tasks. Journal of Rehabilitation Research, 19, 281-296.

Kwon, M., Kim, H., Choi, S. S., Na, D. L., \& Lee, K. H. (1998). A study for spontaneous speech of Korean adults with CIU scoring system. Korean Journal of Communication \& Disorders, 3, 35-49.

Lee, Y., \& Kim, H. (2001). An utterance analysis of conversations and picture description tasks of Korean adults. Korean Journal of Communication \& Disorders, 6, 1-11.

McNeil, M. R., \& Pratt, S. R. (2001). Defining aphasia: some theoretical and clinical implications of operating from a formal definition. Aphasiology, 15, 901-911.

McNeil, M. R., Doyle, P. J., Fossett, T. R., Park, G. H., \& Goda, A. J. (2001). Reliability and concurrent validity of the information unit scoring metric for the story retelling procedure. Aphasiology, 15, 991-1006.

McNeil, M. R., Doyle, P. J., Park, G. H., Fossett, T. R., \& Brodsky, M. B. (2002). Increasing the sensitivity of the Story Retell Procedure for the discrimination of normal elderly subjects from persons with aphasia. Aphasiology, $16,815-822$.

McNeil, M. R., Sung, J. E., Yang, D., Pratt, S. R., Fossett, T. R., Doyle, P. J., \& 
Pavelko, S. (2007). Comparing connected language elicitation procedures in persons with aphasia: concurrent validation of the Story Retell Procedure. Aphasiology, 21, 775-790.

Nicholas, L. E., \& Brookshire, R. H. (1993). A system for quantifying the informativeness and efficiency of the connected speech of adults with aphasia. Journal of Speech, Language, and Hearing Research, 36, 338-350.

Nicholas, L. E., \& Brookshire, R. H. (1995). Presence, completeness, and accuracy of main concepts in the connected speech of non-brain-damaged adults and adults with aphasia. Journal of Speech, Language, and Hearing Research, 38, 145-156.
Pickert, S. M., \& Chase, M. L. (1978). Story retelling: an informal technique for evaluating children's language. The Reading Teacher, 31, 528-531.

Sohn, E. N., \& Kang, S. K. (2006). A study on story retelling in the adults. Journal of Speech \& Hearing Disorders, 15, 71-85.

Stark, J. A. (2010). Content analysis of the fairy tale Cinderella: a longitudinal single-case study of narrative production: "From rags to riches". Aphasiology, 24, 709-724.

Yang, Y. S., \& Kim, S. J. (2006). Narrative discourse in patients with fluency aphasia. Korea Institute of Science and Technology Information, 125-130. 
Appendix 1. 실어증 환자 정보

\begin{tabular}{|c|c|c|c|c|c|c|c|c|c|c|c|c|}
\hline \multirow{3}{*}{ 번호 } & \multirow{3}{*}{ 성별 } & \multirow{3}{*}{ 연령 } & \multirow{3}{*}{$\begin{array}{l}\text { 교육 } \\
\text { 년수 }\end{array}$} & \multirow{3}{*}{$\begin{array}{l}\text { 발병 후 } \\
\text { 개월 수 }\end{array}$} & \multirow{3}{*}{ 병인 } & \multicolumn{6}{|c|}{$K-W A B$} & \multirow{3}{*}{ 실어증 유형(중증도) } \\
\hline & & & & & & \multirow{2}{*}{$\begin{array}{c}\text { 실어증 } \\
\text { 지수(AQ) }\end{array}$} & \multicolumn{2}{|c|}{ 스스로 말하기 } & \multirow{2}{*}{$\begin{array}{l}\text { 알아 } \\
\text { 듣기 }\end{array}$} & \multirow{2}{*}{$\begin{array}{l}\text { 따라 } \\
\text { 말하기 }\end{array}$} & \multirow{2}{*}{$\begin{array}{l}\text { 이름 } \\
\text { 대기 }\end{array}$} & \\
\hline & & & & & & & 내용 전달 & 유창성 & & & & \\
\hline 1 & M & 47 & 17 & 8 & Lt. BG ICH & 71.6 & 8 & 4 & 9 & 9 & 5.8 & $\begin{array}{l}\text { Transcortical motor } \\
\text { (mild to moderate) }\end{array}$ \\
\hline 2 & M & 44 & 16 & 9 & Lt. BG ICH & 90.6 & 9 & 8 & 9 & 9.8 & 9.5 & Anomic (mild) \\
\hline 3 & $\mathrm{~F}$ & 64 & 12 & 10 & Lt. ACA infarction & 88.2 & 9 & 8 & 8.7 & 9.8 & 8.6 & Anomic (mild) \\
\hline 4 & $\mathrm{~F}$ & 43 & 16 & 31 & Lt. SAH & 92.2 & 9 & 9 & 9.6 & 9.8 & 8.7 & Anomic (mild) \\
\hline 5 & M & 61 & 12 & 19 & Lt. BG ICH & 78.1 & 9 & 5 & 8.75 & 9.1 & 7.2 & Anomic (mild) \\
\hline 6 & M & 66 & 9 & 4 & Lt. MCA infarction & 81.5 & 9 & 6 & 8.75 & 8.1 & 8.9 & Anomic (mild) \\
\hline 7 & $\mathrm{~F}$ & 55 & 12 & 38 & Lt. SAH & 86.2 & 9 & 4 & 8.9 & 10 & 7.2 & Anomic (mild) \\
\hline 8 & $\mathrm{~F}$ & 60 & 10 & 35 & Lt. BG ICH & 71.4 & 8 & 4 & 7.7 & 8.2 & 7.8 & $\begin{array}{l}\text { Transcortical motor } \\
\text { (mild to moderate) }\end{array}$ \\
\hline 9 & M & 59 & 12 & 26 & Lt. BG ICH & 88 & 9 & 8 & 8.7 & 9.6 & 8.7 & Anomic (mild) \\
\hline 10 & M & 20 & 12 & 13 & Lt. SAH & 84 & 9 & 7 & 8.9 & 8.9 & 8.2 & Anomic (mild) \\
\hline 11 & $\mathrm{~F}$ & 65 & 12 & 12 & $\begin{array}{l}\text { Lt. top of basilar } \\
\text { occlusion }\end{array}$ & 84.9 & 9 & 8 & 8.15 & 9.4 & 7.9 & Anomic (mild) \\
\hline 12 & $\mathrm{~F}$ & 74 & 12 & 9 & Lt. IVH/ICH & 85.8 & 8 & 8 & 9.3 & 9.8 & 7.8 & Anomic (mild) \\
\hline 13 & M & 43 & 16 & 23 & Lt. SAH & 90.5 & 9 & 8 & 8.95 & 9.8 & 9.3 & Anomic (mild) \\
\hline 14 & M & 61 & 12 & 25 & Lt. MCA infarction & 82.5 & 9 & 6 & 8.05 & 10 & 8.2 & Anomic (mild) \\
\hline 15 & $\mathrm{~F}$ & 56 & 12 & 23 & Lt. BG ICH & 70.4 & 8 & 4 & 7.9 & 7.6 & 7.7 & $\begin{array}{l}\text { Transcortical motor } \\
\text { (mild to moderate) }\end{array}$ \\
\hline
\end{tabular}

$K-W A B=$ Korean version of Western Aphasia Battery (Kim \& Na, 2001); $A Q=$ Aphasia Quotient; $B G=$ basal ganglia; ICH=intra cerebral hemorrhage; $A C A$ infarction= anterior cerebral artery infarction; SAH=sub-arachnoid hemorrhage; MCA= middle cerebral artery; IVH=intraventricular hemorrhage.

Appendix 2. 정상 집단 정보

\begin{tabular}{|c|c|c|c|c|c|c|c|c|}
\hline 번호 & 성별 & 연령 & 교육년수 & K-MMSE & SVLT-I & SVLT-D & SVLT-R-TP & SVLT-R-FP \\
\hline 1 & $M$ & 20 & 12 & 30 & 24 & 10 & 12 & 1 \\
\hline 2 & $M$ & 44 & 16 & 29 & 20 & 8 & 10 & 0 \\
\hline 3 & $M$ & 45 & 16 & 30 & 22 & 9 & 11 & 1 \\
\hline 4 & $M$ & 49 & 16 & 30 & 26 & 11 & 12 & 0 \\
\hline 5 & $M$ & 60 & 12 & 30 & 16 & 7 & 12 & 1 \\
\hline 6 & $M$ & 60 & 11 & 30 & 18 & 8 & 12 & 3 \\
\hline 7 & $M$ & 67 & 9 & 29 & 17 & 5 & 12 & 2 \\
\hline 8 & $F$ & 44 & 14 & 29 & 24 & 9 & 11 & 0 \\
\hline 9 & $\mathrm{~F}$ & 57 & 12 & 29 & 21 & 9 & 12 & 2 \\
\hline 10 & $\mathrm{~F}$ & 62 & 12 & 29 & 17 & 9 & 11 & 2 \\
\hline 11 & $\mathrm{~F}$ & 59 & 11 & 29 & 18 & 6 & 11 & 2 \\
\hline 12 & $\mathrm{~F}$ & 59 & 12 & 27 & 20 & 6 & 12 & 1 \\
\hline 13 & $\mathrm{~F}$ & 64 & 12 & 28 & 21 & 6 & 10 & 2 \\
\hline 14 & $\mathrm{~F}$ & 64 & 12 & 30 & 18 & 6 & 11 & 1 \\
\hline 15 & $\mathrm{~F}$ & 75 & 12 & 29 & 23 & 6 & 11 & 1 \\
\hline
\end{tabular}

K-MMSE = Korean-Mini Mental State Examination (Kang, Na, \& Hahn, 1997); SVLT=Seoul Verbal Learning Test; I=immediate recalls; $D=$ delayed recalls; R= recognition; $\mathrm{TP}=$ true positive; $\mathrm{FP}=$ false positive. 
Appendix 3. 이야기 다시말하기에 사용된 그림 자극

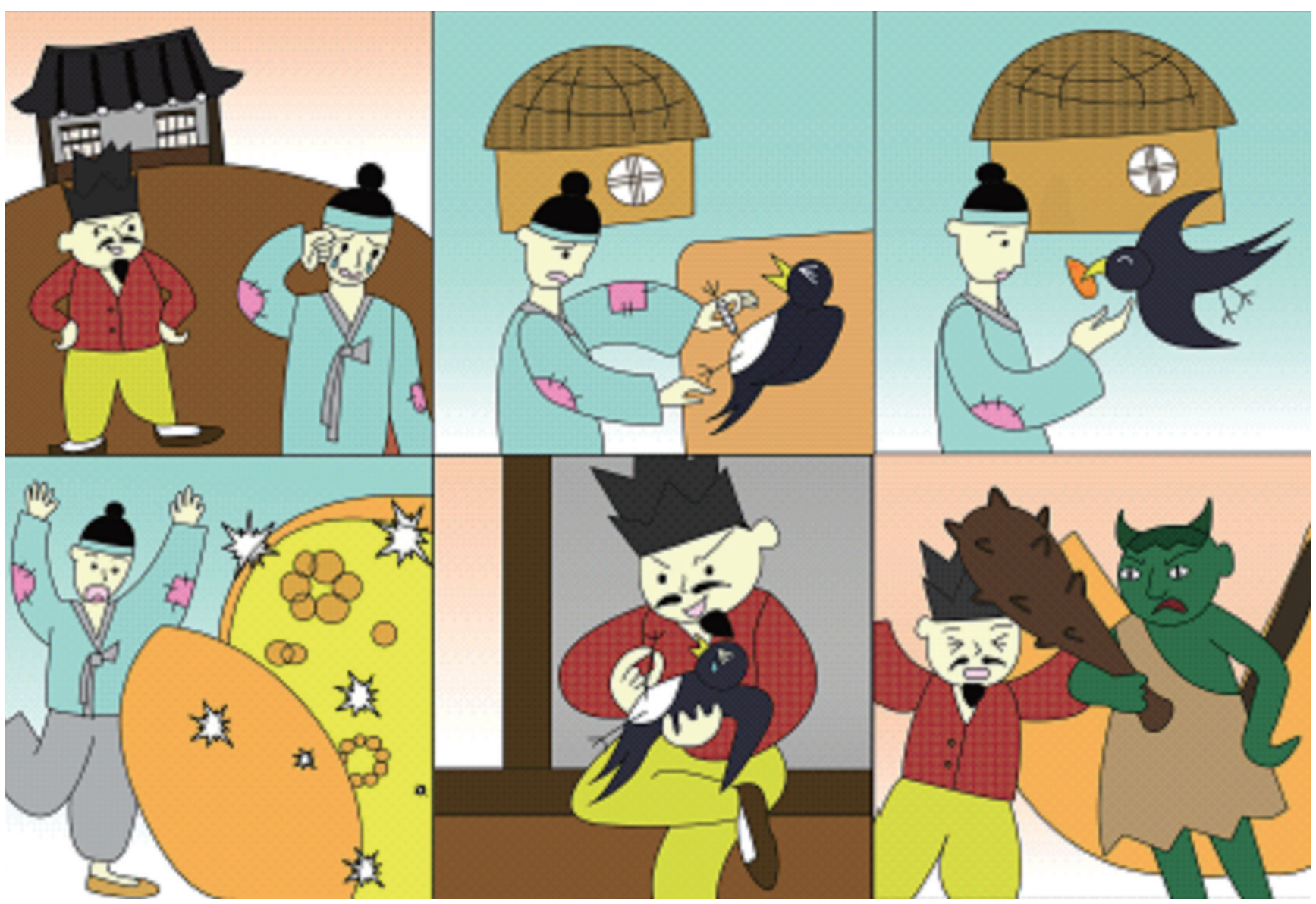


Appendix 4. IU 분석 기준

\begin{tabular}{ll}
\hline 요소 & \multicolumn{1}{c}{ 분석 기준 } \\
\hline $\mathrm{IU}$ & 1. 분석이 가능한 정도의 말명료도를 보이는 단어 혹은 구를 포함한다. \\
& 2. 이야기와 관련되며 정확한 정보를 제공하는 단어 혹은 구를 포함한다. \\
& 3. 반드시 IU와 문법적으로 일치한 형태를 산출하지 않아도 된다. \\
& 4. 목표 IU와 동일하게 사용되는 유의어도 IU에 포함한다. \\
& 5. 명사, 대명사, 고유명사, 동사, 형용사, 부사, 관형사*, 조사, 접속사 포함한다. \\
& 6. 의미는 유사하나 단어를 추가하거나 동사를 서술한 경우 IU에서 제외한다. \\
& 7. 수정을 위해 같은 IU를 반복할 경우 마지막 산출을 최종의 것으로 간주하며 중복된 IU는 포함하지 않는다.
\end{tabular}

McNeil et al., 2001에서 부분 수정.

본 연구자가 첨가.

Appendix 5. 언어측정 변수 분석 기준

\begin{tabular}{|c|c|}
\hline 요소 & 분석 기준 \\
\hline 총 발화 수 ${ }^{a}$ & $\begin{array}{l}\text { - 종결어미가 있으면 끊어준다 단, 종결어미가 뒤에 내용상 이어지는 문장 성분이 나오면 같은 발화 안에 포함한다. } \\
\text { - 접속사(예: 그리고)가 나오면 종결어미 바로 뒤에 끊는다. } \\
\text { - 문맥이 연결되는 경우라도 5초 이상의 시간 간격이 있는 경우에는 끊는다. } \\
\text { - 연결어미(예: -고)로 계속 이어지는 경우, 억양의 큰 변화나 } 5 \text { 초 이상의 시간 간격이 있는 곳에서 끊는다. 단, 억양의 큰 변화나 긴 시 } \\
\text { 간 간격이 없이 계속해서 발화가 ‘-고’ 등으로 이어지는 경우, 두 번째 ‘-고'까지를 한 발화로 간주하여 끊는다. }\end{array}$ \\
\hline 낱말 수 ${ }^{b}$ & $\begin{array}{l}\text { - 모든 자립형태소는 개별적인 낱말로 계산한다. } \\
\text { - 자랍형태소에 붙는 의존형태소(예: 조사)는 개별적인 낱말로 계산한다. } \\
\text { - 준자립어(의존명사, 보조용언)는 개별적인 낱말로 계산한다. } \\
\text { - 낱말 또는 어절에 붙어 그 말과 다른 말과의 관계를 표시하는 조사(예: 격조사, 접속조사, 보조사)는 하나의 낱말 수로 계산한다. } \\
\text { - 통상적으로 하나의 개념으로 굳어버린 복합용언(예: 내놓아라, 들어오다) 혹은 복합어(예: 서울대공원)은 1개의 낱말 수로 분석한다. } \\
\text { - 존대적 표현인 서술격조사 ' 요'는 개별 낱말로 취급하나 '요'가 서술격 조사로 사용되지 않고 습관적인 언어 형태의 하나인 '간투사'로 } \\
\text { 사용되었거나 체언 옆에 붙어서 존대만을 나타내는 경우에는 낱말로 분류하지 않는다. } \\
\text { (예: '이거 । 사과-예요' -낱말 수 3개, '선물(요) 받으세요' 낱말 수 2개) }\end{array}$ \\
\hline $\begin{array}{l}\text { 분당 낱말 수c } \\
\text { (낱말 수/총 발화시간) }\end{array}$ & $\begin{array}{l}\text { - 내용에 관계없이 알아들을 수 있을 정도의 명료도를 가진 낱말의 수를 세어 1분당 낱말 수로 환산한다. } \\
\text { - 착어나 마비말장애 등으로 인한 발음상의 왜곡이 있어도 의미가 통할 정도의 명료도를 가진 낱말이면 포함한다. } \\
\text { - -어’등과 같은 무의미한 음절의 간투사는 제외한다. }\end{array}$ \\
\hline 발화 당 낱말 수 & $\begin{array}{l}\text { - 한 발화당 산출한 단어의 수를 산출한다. } \\
\text { - 무의미한 간투사는 제외한다. }\end{array}$ \\
\hline CIU 수 ${ }^{d}$ & $\begin{array}{l}\text { - 알아들을 수 있을 정도의 명료도를 가지며, 내용이 주제 및 과제에 적절하고 올바른 정보를 제공하는 낱말을 말한다. } \\
\text { - 부적절한 내용을 전달하는 낱말은 제외한다. } \\
\text { - 자가수정한 경우는 마지막 반응을 분석한다. } \\
\text { - 반복된 정보는 } 1 \text { 번만 세고, 강조하기 위한 경우는 반복되어도 따로 센다. } \\
\text { - 주제와 관계없는 개인의 느낌이나 언급은 제외한다. } \\
\text { - 그림이나 주제에 대한 정보를 주지 않는 과제에 대한 언급은 제외한다. } \\
\text { - 잘못된 시작이나 끝을 맺지 못한 낱말은 제외한다. } \\
\text { - 그림의 인물이나 사건, 장소 등에 관해 불확실성을 표현하는 낱말은 포함시킨다. } \\
\text { - 결속장치가 아닌 무의미한 간투어로 쓰인 접속사는 제외한다. } \\
\text { - 간투사는 제외한다. } \\
\text { - 특정한 참조물이 없는 지시어는 제외한다. } \\
\text { - 문법적으로 완전하지 않아도 알아들을 수 있고, 주제에 적절하다고 판단되는 경우 포함시킨다. } \\
\text { - 주제에 적절하고 그림 또는 과제에 대한 적절한 언급인 경우, 감탄사도 포함한다. }\end{array}$ \\
\hline $\begin{array}{l}\text { CIU 비율c (CIU 수/총 낱말 수 } \\
\times 100)\end{array}$ & $\begin{array}{l}\text { - 전체 낱말 중에서 내용상 적절하고 올바른 정보를 제공하는 낱말의 비율을 산출한다. } \\
\text { - CIU 비율이 높을수록 효과적으로 정보를 전달하는 능력이 높다. }\end{array}$ \\
\hline $\begin{array}{l}\text { 분당 CIU 수 (CIU 수/ } \\
\text { 총 발화시간) }\end{array}$ & $\begin{array}{l}\text { - 알아들을 수 있을 정도의 명료도를 가지며 내용이 주제 및 과제에 적절하고 올바른 정보를 제공하는 낱말의 수를 세어 1분당 CIU 수 } \\
\text { 로 환산한다. }\end{array}$ \\
\hline $\begin{array}{l}\text { 분당 CIU 비율 (CIU 비율/ } \\
\text { 총 발화시간) }\end{array}$ & - CIU 비율을 산출하여 1분당 CIU 비율로 환산한다. \\
\hline
\end{tabular}

aLee \& Kim, 2001, ' Kim, 2002, 'Kwon, Kim, Choi, Na, \& Lee, 1998, `Nicholas \& Brookshire, 1993. 


\section{국문초록}

\section{실어증 환자의 시각 단서 유무에 따른 정보단위 분석 기반 이야기 다시말하기 특성}

\section{김예나 · 성지은}

이화여자대학교 대학원 언어병리학과

배경 및 목적: 본 연구의 목적은 시각 단서 유무에 따른 실어증 환자의 이야기 다시말하기 수행을 정보단위(information unit, IU)분석 을 통해 살펴보는 것이다. 또한, 한국어 실어증 환자를 대상으로 IU 분석의 유용성을 살펴보기 위해 언어측정 변수 및 중증도와의 상관 관계를 살펴보았다. 방법: 실어증 환자와 정상성인 각각 15 명을 대상으로, 시각 단서가 제시되는 시각-청각 조건과 제시되지 않는 청각 조건에서 이야기 다시말하기 과제를 실시하였다. IU 체크리스트를 활용하여 IU 빈도, IU 비율(\%), 분당 IU 빈도, 분당 IU 비율(\%)을 산 출하였다. 결과: 이원혼합분산분석을 실시한 결과, 모든 IU 측정 변수에서 실어증 집단이 정상 집단에 비해 유의하게 낮은 수행을 보였 다. 시각 단서에 따른 주효과가 IU 빈도 및 비율(\%)에서는 유의하였으나 분당 IU 빈도 및 비율(\%)에서는 유의하지 않았다. 또한 시각 단 서에 따른 집단 간 이차상호작용이 모두 유의하지 않았다. IU와 언어측정 변수, 중증도(AQ) 그리고 실어증검사의 하위항목 간의 상관 관계를 살펴본 결과, IU 측정 변수와 CIU와 같은 의미론적 측면의 변수들과 높은 상관관계가 나타났으며, 중증도(AQ), 유창성, 따라말 하기, 이름대기와도 유의한 상관관계를 보였다. 논의 및 결론: 시각 단서가 제시될 때 실어증 환자의 발화량이 증가하는 것으로 나타났 다. 또한 IU 분석체계는 기존의 언어측정 변수와 실어증 중증도 그리고 실어증검사의 하위항목과 유의한 상관관계를 보이는 변수로 나 타났다. 즉, IU 분석은 임상에서 효율적으로 사용이 가능한 분석방법임을 시사하고 있다.

핵심어: 실어증, 이야기 다시말하기, 시각 단서, 정보단위(IU)

이 논문은 2016년 대한민국 교육부와한국연구재단의 지원을 받아 수행된 연구임(No. NRF-2017R1A2B4006604).

\section{참고문헌}

강연욱, 나덕렬, 한승혜(1997). 치매환자들을 대상으로 한 K-MMSE의 타당도연구. 대한신경과학회지, 15, 300-308.

강연욱, 장승민, 나덕렬(2012). 서울신경심리검사 2판. 서울: 휴브알엔씨.

구서진, 최현주(2015). 대화와 그림설명 과제를 통한 브로카 실어증 환자의 자발화 산출 특성. 재활복지, 19, 281-296.

권미선, 김향희, 최상숙, 나덕렬, 이광호(1998). 한국 성인의 자발화 분석에 관한 연구: CIU 분석법을 중심으로. 언어청각장애연구, 3, 35-49.

김영태(2002). 아동언어장애의 진단 및 치료. 서울: 학지사.

김정완, 김향희, 남궁기, 김세주, 김덕용(2006). 알츠하이머성 치매환자의 발화특성. 언어청각장애연구, 11, 82-98.

김하나(2014). 정보단위(IU)에 따른 경도인지장애군의 연속 발화분석 방법의 타당성 연구. 이화여자대학교 대학원 석사학위논문.

김하나, 성지은(2014). 노화에 따른 이야기 다시 말하기 수행력 및 작업기억과의 상관관계 연구. 특수교육, 13, 7-24.

김향희(1996). 운동실조형 마비성구음장애에 적용되는 지각적, 음향학적, 생리학적 도구에 관하여: 환자사례를 중심으로. 제 2 회 음성학학술대회자

료집, 9-22.

김향희, 나덕렬(2001). 파라다이스·한국판-웨스턴실어증검사. 서울: 파라다이스 복지재단.

손은남, 강수균(2006). 청년기와 노년기의 이야기 담화 능력 특성 연구. 언어치료연구, 15, 71-85.

양용선, 김수진(2006). 유창성 실어증자의 이야기 이해와 산출 능력. 한국과학기술정보연구원, 125-130.

이영미, 김향희(2001). 대화와 그림설명과제를 통한 한국성인 발화의 비교 분석. 언어청각장애연구, 6, 1-11.

임은주, 권미선, 심현섭(2001). ADHD 경중도에 따른 유창성 실어증환자의 정보전달능력에 관한 연구. 언어청각장애연구, 6, 374-391.

정윤희(2009). 알츠하이머 치매환자의 과제 유형에 따른 정보 전달 능력에 관한 연구. 이화여자대학교 대학원 석사학위논문.

하지완, 정윤희, 심현섭(2009). 알츠하이머 치매 및 치매의심 집단과 정상 노인의 발화 비교분석을 통한 삽입어(filler)의 기능 연구. 언어청각장애연구,

14, 514-530. 